http://diakronika.ppj.unp.ac.id

DOI: https://doi.org/10.24036/diakronika/vol21-iss2/204

Received 12 Jul, Revised 09 Des, Accepted 31 Des

\title{
Guru dan Kualitas Pendidikan di Indonesia Masa Kolonial dan Pasca Kemerdekaan
}

\author{
Siti Fatimah, Firza \\ sitifatimah@fis.unp.ac.id firzaa@fis.unp.ac.id \\ Universitas Negeri Padang
}

\begin{abstract}
The problem of teachers and the quality of education are like two sides of a coin that has been going on since the colonial era in Indonesia. The purpose of this article is to analyze teachers and the quality of education in colonial and post-independence Indonesia. The research method uses a comparative method with a historical approach (historical). The results of research in 1892 that the need for teachers was very urgent, so the government took a policy of appointing teachers without going through teacher education. As a result, there is a decline in the quality of education and does not bring change. Policies were improved during this period, (1) a large increase in teacher salaries; (2) allow social symbols of honor; (3) Graduates of teacher schools (kweekschool) can be placed in any government position, and as a result, the quality of teachers and education increases. So that the teacher becomes one of the coveted professions of society at this time. Postindependence until now the same pattern also occurs. During the New Order era, in the 1980 s to be precise, he was known as the "galodo" teacher. Since the 2000s, the government has issued several policies that are similar to what the colonial government had done. Teacher salaries were increased through teacher certification, teacher education programs (both in and out of office) were also implemented. However, to date, no significant changes have been seen, even though various policies have been implemented. The conclusion of this study is that there is the same policy pattern, but the results are different.
\end{abstract}

Keywords: Teachers, Quality of Education, Education, Colonial Period, PostIndependence

\begin{abstract}
Abstrak
Persoalan guru dan kualitas pendidikan ibarat dua sisi mata uang yang berlangsung semenjak zaman kolonial di Indonesia. Tujuan dari artikel ini untuk menganalisis guru dan kualitas pendidikan pada masa kolonial dan pasca kemerdekaan Indonesia. Metode penelitian menggunakan metode komparasi dengan pendekatan sejarah (historis). Hasil penelitian pada tahun 1892, kebutuhan guru sangat mendesak, sehingga pemerintah kolonial mengambil kebijakan mengangkat guru tanpa melalui pendidikan guru. Akibatnya terjadi kemerosotan kualitas pendidikan dan tidak membawa perubahan. Kebijakan diperbaiki pada masa ini, (1) kenaikan gaji guru yang cukup besar; (2) mengizinkan lambang-lambang sosial kehormatan; (3) Tamatan sekolah guru (kweekschool) dapat ditempat dalam setiap jabatan pemerintah, dan hasilnya kualitas guru dan pendidikan menjadi meningkat. Sehingga guru menjadi salah satu profesi yang didambakan masyarakat pada masa ini. Pasca kemerdekaan
\end{abstract}


Siti Fatimah, Firza

Guru dan Kualitas Pendidikan di Indonesia Masa Kolonial

dan Pasca Kemerdekaan

sampai saat ini pola yang sama juga terjadi. Pada masa Orde Baru, tepatnya pada tahun 1980-an, dikenal dengan guru "galodo". Semenjak tahun 2000-an, pemerintah melahirkan beberapa kebijakan yang mirip dengan apa yang sudah dilakukan pemerintah kolonial. Gaji guru dinaikkan melalui sertifikasi guru, program pendidikan guru (baik dalam jabatan maupun di luar jabatan) juga mulai diterapkan. Namun, sampai pada hari ini belum terlihat perubahan yang signifikan, meskipun berbagai kebijakan sudah dilakukan. Simpulan penelitian ini terdapat pola kebijakan yang sama, namun hasilnya berbeda.

Kata Kunci: Guru, Kualitas Pendidikan, Pendidikan, Masa Kolonial, Pasca Kemerdekaan

(c) (i) (2) This work is licensed under the Creative Commons Attribution-ShareAlike 4.0 ${ }_{\mathrm{EY}}$ SA International License

\section{Pendahuluan}

Pendidikan sangat erat kaitannya dengan kualitas guru (Grossman \& McDonald, 2008; Lak, A., Gheitasi, M., \& Timothy, 2020). Kualitas guru adalah fenomena yang urgen di dalam sejarah pendidikan. Berbicara tentang pendidikan adalah sebuah persoalan yang tidak pernah kering untuk didiskusikan (Raharjo, 2012; Siregar, 2020).

Hal ini bisa dilihat dari zaman pra sejarah sampai hari ini. Guru memberikan pengaruh dan dampak yang sangat besar dalam perkembangan pendidikan Pada zaman Kolonial, sehingga kualitas guru terjadi pasang surut. Hal ini terjadi karena belum adanya standar indikator kualitas guru sehingga kualitas pendidikan tidak merata. Indikator kualitas guru terdiri dari management, anggaran dan Pendidikan yang sangat berkontribusi bagi kemajuan pendidikan (Firdianti, 2018; Sormin, 2021). Manajemen guru merupakan pengordinasian seluruh aktivitas kerja seorang guru sebagai bentuk peningakatan tiga aspek peserta didik yaitu afektif, kognitif dan psikomotor.

Manajemen yang baik maka akan memberikan pendidikan yang berkualitas serta memberikan pengalaman belajar yang bermakna bagi peserta didik. Hal lain ialah anggaran, dengan diberikannya kesejahteraan yang memadai maka (Munirom, 2021; Purba et al., 2021; Shehabat \& Berrish, 2021) kualitas guru pun akan meningkat hal ini juga diungkapn dalam penelitian Varkey Foundation, University of Sussex, dan National Institute of Economic and Social Research (NIESR) (Chu et al., 2021). Laporan berjudul Global Teacher Status (GTS) Index tahun 2018 memaparkan hubungan antara status guru di masyarakat dan hasilnya terhadap pendidikan. Indikator ketiga ialah Pendidikan, bagi seorang pendidik kualitas pendidikan yang dimiliki sangat 
menentukan kualitas yang dimilikinya maka kesesuaian antara kualifikasi pendidikan dan profesi sangat berkaitan erat.

Untuk menghasilkan pendidikan yang bermutu, dibutuhkan guru profesional serta kualitas pendidikan yang baik. Guru yang profesional memiliki kualitas dan memenuhi kualifikasi yang telah ditetapkan. Undang-undang nomor 14 tahun 2005 tentang guru dan dosen pasal 10 ayat 1., di dalam aturan tersebut dijelaskan kompetensi yang harus dimiliki oleh guru 1) Kompetensi Pedagogoi, 2) Kompetensi Kepribadian, 3) Kompetensi Sosial dan 4) Kompetensi Profesional (Febriana, 2021). Dari undang-undang tersebut, seorang pendidikan yang profesional harus menguasai keempat kompenen tersebut, sehingga dapat melahirkan generasi yang memberikan pengaruh dan perubahan untuk bangsa Indonesia.

Terdapat beberapa kemiripan kebijakan yang diterapkan guru antara masa kolonial dan reformasi, yaitu sama-sama berasal dari sekolah keguruan meskipun pada masa kolonial masih berasal dari sekolah keguruan rendah. Tidak adanya rancangan pendidikan yang sistematis, hal ini membuat guru belum dapat merumuskan pembelajaran dengan baik, dan tujuan dari pendidikan ialah untuk mengisi kekosongan pegawai atau pekerja sehingga guru belum memiliki pandangan jauh untuk membawa pendidikan di Indonesia saat itu.

Namun, jika ingin menjawab pertanyaan tentang bagaimana perbandingan kualitas pendidikan saat ini dan dahulu adalah suatu hal yang sangat rumit dan sulit. Kompleksitas yang terjadi di dalam pendidikan Indonesia memberikan pengaruh yang besar (Risdiany, 2021). Salah satu contoh adalah peraturan dan kebijakan yang diberlakukan. Setiap kebijakan yang dikeluarkan oleh pemerintah pasti melahirkan dua cara pandang yang berbeda. Ada yang setuju dan ada yang menolak untuk diimplementasikan dengan alasan tertentu. Kondisi seperti ini bukan merupakan suatu hal yang baru di dalam sejarah pendidikan Indonesia. Secara historis pada masa Kolonial pemerintah sangat sukar mendapatkan murid, karena anak priayi tidak ingin menjadi guru dan lebih senang menjadi pegawai pemerintah. Kemudian pemerintah membuat kebijakan melalui: (1) kenaikan gaji guru yang cukup besar; (2) mengizinkan lambang-lambang sosial kehormatan; (3) Tamatan sekolah guru (kweekschool) dapat diterima dalam setiap jabatan pemerintah.

Hal yang sama berlanjut pada pasca kemerdekaan sampai saat ini. Pada masa Orde Baru, tepatnya pada tahun 1980-an, dikenal dengan guru "galodo", yaitu pengangkatan guru juga dilakukan secara besar-besaran tanpa melalui pendidikan profesi guru. Para guru yang diangkat semenjak tahun 1980-an ini, 
sudah hampir memasuki pensiun karena sudah bertugas lebih kurang selama 30 tahun. Semenjak tahun 2000-an, pemerintah mencoba melahirkan beberapa kebijakan yang mirip dengan apa yang sudah dilakukan pemerintah kolonial. Gaji guru dianaikkan melalui sertifikasi guru, program pendidikan guru (baik dalam jabatan maupun di luar jabatan) juga mulai diterapkan (A. S. Anwar, 2020; Wijaya, C., Nasution, T., Al Qadri, M., Fuadi, A., \& Anwar, 2021). Namun, sampai pada hari ini belum terlihat perubahan yang signifikan, meskipun berbagai kebijakan tersebut sudah diberlakukan.

Fenomena yang sama pada waktu yang berbeda memberikan pangalaman bagi generasi sekarang tentang kualitas pendidikan Indonesia. Persoalan kualitas pendidikan di Indonesia masih menjadi masalah yang sering diperbincangkan (Kurniawan, 2016; Priscilla, 2019). Tidak bisa menyalahkan satu pihat tertentu, karena masih menjadi hal yang sangat rumit dan sulit dalam melihat kualitas pendidikan Indonesia. Beberapa faktor yang menjadi alasananya adalah pertama, apa yang menjadi ukuran untuk menjawab persoalan kualitas pendidikan. Kedua, aspek dan indikator apa yang digunakan untuk mengukur dan menentukan kualitas pendidikan, dan yang ketiga, bagaimana dan kemana sesungguhnya dan perubahan pendidikan Indonesia. Tiga hal tersebut tentunya sangat membutuhkan data dengan uraian dan penjelasan yang bisa dipertanggungjawabkan.

Perubahan kualitas pendidikan dari waktu ke waktu, tentu tidak terbatas hanya pada dimensi guru sebagai penyebab rendah atau tingginya kualitas pendidikan di Indonesia. Jika dianalisis dengan menggunakan konsep paedagogik Kritis dan Tranformatif bahwa Pendidikan bukan semata-mata transmisi kebudayaan dan ilmu pengetahuan bahkan merupakan proses dekonstruksi dan rekonstruksi dari kebudayaan itu sendiri (Giroux, 2020; Ukpokodu, 2009). Terdapat tiga masalah yang sangat progresif di bidang pendidikan: pertama, mengkritik prinsip Chlid Centered Education; kedua, memberikan arti besar terhadap peranan guru untuk menjadikan pendidikan sebagai agen perubahan sosial; ketiga, perubahan ekonomi sebagai salah satu syarat untuk perbaikan pendidikan (Counts, 1978; Smith, 2019; Tilaar, 2003). Berkualitasnya pendidikan sangat ditentukan oleh ketiga faktor tersebut.

Namun dari ketiga faktor tersebut, maka faktor yang berhubungan dengan peran guru lebih mendominasi. Faktor pertama dan ketiga sesungguhnya sangat memberi kontribusi yang dominan juga terhadap peran guru. Tujuan tulisan dalam artikel ini mengungkap: pertama, perbandingan guru dan kualitas pendidikan pada masa sebelum dan sesudah kemerdekaan; kedua, indikator apa yang digunakan untuk mengukur dan menentukan kualitas pendidikan; dan 
ketiga, Alternatif kebijakan seperti apa yang harus dilakukan oleh pemerintah untuk meningkatkan mutu guru dan kualitas pendidikan jika ditinjau dari perspektif sejarah. Penelitian ini menjadi penting karena melahirkan sebuah penelitian komparasi serta mengungkap fakta-fakta baru yang ada dalam sekolah keguruan masa itu. Model komparasi dalam penelitian sejarah masih langka dilakukan peneliti.

\section{Metode Penelitian}

Penelitian ini menggunakan metode studi komparatif. Pada penelitian ini membandingkan dua variabel pada waktu yang berbeda (Hans, 2012; Phillips, 2006). Penelitian ini menggunakan pendekatan historis dalam menelaah sumbersumber yang berisi informasi mengenai masa lampau dan dilaksanakan secara sistematis (Heyman, J., \& Jacques, 1998; Mahoney, J., \& Rueschemeyer, 2003). Data yang digunakan dalam penelitian bersumber dari buku, artikel ilmiah dan dokumen yang relevan lainnya. Pencarian data disebut dengan Heuristik, yang merupakan langkah permulaan di dalam semua penulisan sejarah. Pada tahap heuristik maka akan dicari data terkait dengan pendidikan masa kolonial dan pasca kemerdekaan. Setelah itu dilakukan penilaian atau pengujian terhadap data yang disebut kritik sumber, data yang di dapat terkait Pendidikan masa kolonial dan pasca kemerdekaan akan di lihat relevansinya dan kesesuaian dengan tema penelitian. Tahap terakhir yaitu penyajian yang sistematis dari hasil heuristik dan kritik. Penyajian dilakukan sesuai batas-batas kebenaran yang objektif.

\section{Hasil dan Pembahasan}

\section{Pentingnya guru sebagai agen perubahan}

Konsep guru sesungguhnya sudah lama dikenal dalam sejarah dan budaya bangsa Indonesia. Pada masa sejarah Indonesia Klasik dikenal istilah resi, begawan, wiku, pandhita, dahyang, guru dan hajar, yang kesemuanya memiliki makna yang hampir sama, yaitu pendidik dan guru. Konsep guru ketika itu memiliki makna yang khusus, yakni guru berkaitan dengan pengetahuan agama, filsafat hidup, dan persoalan-persoalan spiritual lain (Raharjo, 2012; Wardani, 2010). Guru sebagaimana disebutkan di atas, memilki status yang cukup tinggi karena dalam strata agama Hindu yang berdasarkan pada Kasta, mereka merupakan kasta Brahmana. Seorang Kasta Brahmana memiliki hirarki sosial di atas kasta-kasta yang lain, yaitu: kesatria, (raja, bangsawan, tentara dan birokrat), weisia (pedagang dan usahawan), dan sudra 
Siti Fatimah, Firza

Guru dan Kualitas Pendidikan di Indonesia Masa Kolonial

dan Pasca Kemerdekaan

(petani, tukang dan buruh), serta paria (pengemis). Status sosial yang tinggi tersebut bukan karena tingkat penghasilannya yang tinggi, tetapi melainkan berdasarkan keluasan ilmu yang mereka miliki (Bugge, 2020; Mirowsky \& Ross, 2017).

Setelah Islam masuk ke wilayah nusantara, khususnya di awal-awal masuknya agama Islam sekitar abad ke7-12, konsep guru dalam pengertian pengajar spiritual dan persoalan-persoalan kerohanian masih tetap dipertahankan. Guru mencakup penganjur dan penyebar agama Islam yang umumnya memiliki murud-murid di pesantren-pesantren. Dengan demikian, para ulama pengajar dan penganjur agama Islam tersebut, antara lain disebut syekh, kyai, maulana, tuanku guru, ustadz, dan semacamnya dikelompokkan sebagai guru (Arifin, 2019; Nur, 2011).

Konsep guru mengalami perubahan makna yang mendasar ketika zaman kolonial (Agung, 1993; Dyokta, 2020). Hal ini sejalan dengan orientasi kebijakan pemerintah kolonial ketika itu. Pendidikan kolonial merubah paradigma dari pendidikan kerohanian dengan pendidikan keduniaan dengan menjadikan konsep guru tidak lagi sebagai pendidik urusan spiritual, melainkan guru juga mengajarkan urusan-urusan keduniawian. Guru disepadankan dengan leerar dalam bahasa Belanda, dan teacher dalam bahasa Inggris yang berarti orang yang memiliki pekerjaan, mata pencaharian atau profesinya dengan mengajar (Wasino, W., \& Hartatik, 2019).

Setelah era reformasi terjadi di Indonesia, Undang-Undang No. 14 tahun 2005 membagi tingkatan guru kepada: guru, dosen dan guru besar. Guru didefinisikan sebagai pendidik professional (Wijaya, 2018), dengan tugas utama mendidik, mengajar, membimbing, mengarahkan, melatih, menilai, dan mengevaluasi peserta didik jalur pendidikan formal mulai dari pendidikan dasar hingga menegah. Sedangkan dosen merupakan pendidik professional dan ilmuan dengan tugas utama mentransformasikan, mengembangkan, menyebarluaskan ilmu pengetahuan, teknologi dan seni melalui pendidikan, penelitian dan pengabdian masyarakat.

Jika dihubungkan dengan fungsi dan peran guru sebagai agen perubahan, dapat dikatakan bahwa kemajuan dan kualitas sebuah bangsa sangat ditentukan oleh kualitas guru juga. Guru yang berkualitas dipastikan akan melahirkan generasi yang berkualitas dan sebaliknya. Namun yang menjadi persoalan di negara Indonesia adalah dari sepuluh orang guru tidak lebih dari tiga orang yang memenuhi standar atau kriteria sebagai seorang guru yang normal saat ini (A. S. Anwar, 2020; M. Anwar, 2018). 


\section{Guru zaman Kolonial}

Sekolah guru (Kweekschool) pertama dibuka di kota Solo pada tahun 1852, dan Kweekshool atau Normalschool di Bukittinggi tahun 1856 (Nasution, 2008; Zed, 1995). Sekolah-sekolah ini menghasilkan lebih dari 200 guru dari tahun 1887-1892. Sebelum sekolah guru dapat menghasilkan jumlah guru yang cukup, tidak dilakukan persyaratan apa-apa untuk dapat masuk sekolah guru. Pada saat ini kebutuhan guru sangat mendesak sekali, sehingga ada kelas yang sangat besar jumlah siswanya. Pada tahun 1859 seorang guru di Kaibobo, Seram harus menghadapi 285 murid dan di Manado 260 murid dalam satu kelas (Nasution, 2008). Kebutuhan yang mendesak akhirnya pemerintah kolonial pada tahun 1892 memutuskan mengangkat guru tanpa melalui pendidikan guru. Hal yng sama pernah terjadi pada masa orde baru, yakni sektar tahun 1980-an.

Pada mulanya sukar mencari siswa untuk masuk sekolah guru, dan anakanak priayi yang masuk sekolah guru hanya merupakan batu loncatan untuk memperoleh pekerjaan sebagai pegawai pemerintah, yang dianggap mereka lebih terhormat. Tidak ada persyaratan untuk masuk sekolah guru, dan tidak ada sekolah yang mempersiapkan persyaratan untuk itu. Satu-satunya syarat adalah usia minimum 14 tahun dan maksimum 17 tahun. Kemudian, kualitas sekolah guru baru mulai meningkat pada tahun 1871 ketika kurikulumnya mulai sejajar dengan sekolah menengah, dengan mata ajar: bahasa daerah, dengan buku karangan berbahasa Belanda, berhitung, geometri elementer, sejarah, ilmu alam, menggambar, paedagogik dalam bentuk teori dan praktek, menulis tangan dalam huruf latin, jawa dan lain-lain, tergantung kepada daerahnya masingmasing.

Pada tahun 1892 dilakukan reorganisasi dalam dalam pendidikan guru, namun tidak serta merta membawa perubahan yang radikal, karena kurikulumnya masih sama. Kebutuhan sekolah rendah mulai mempengaruhi sekolah guru. Sampai tahun 1892 kurikulum sekolah dasar ditentukan oleh sekolah guru. Semua mata pelajaran sekolah guru, kecuali ilmu mendidik boleh diajarkan di sekolah rendah. Kebutuhan akan bahasa Belanda di Sekolah Kelas Satu menyebabkan bahasa Belanda mulai diajarkan kembali di sekolah guru, yang sebelumnya sempat dihapuskan. Reorganisasi 1892 menciptakan dua jenis sekolah: Sekolah Kelas Satu terutama bagi anak golongan atas, dan Sekolah Kelas Dua bagi orang biasa. Lulusan sekolah guru biasanya dijadikan kepala sekolah baik di Sekolah Kelas Satu maupun di Sekolah Kelas Dua.

Sebagaimana yang telah disinggung pada bagian terdahulu bahwa pada mulanya Sekolah Guru sukar untuk mendapatkan murid, karena anak-anak priayi pada umumnya enggan menjadi guru dan lebih senang menjadi pegawai 
Siti Fatimah, Firza

Guru dan Kualitas Pendidikan di Indonesia Masa Kolonial

dan Pasca Kemerdekaan

pemerintah. Untuk menarik murid lebih banyak masuk sekolah guru, pemerintah menetapkan kenaikan gaji guru yang cukup besar dan mengizinkan lambang-lambang kehormatan sosial. Pada saat yang sama dikeluarkan pula peraturan pemerintah yang menetapkan bahwa guru lulusan Kweekschool dapat ditempatkan dalam setiap jabatan pemerintah (Nasution, 2008). Akhirnya jumlah pelamar sekolah guru menjadi meningkat, sehingga setelah tahun 1892, diadakan ujian seleksi, dan mereka yang sudah luluspun diadakan kembali seleksi khusus dan memenuhi persyaratan tertentu. Akibatnya, hanya 10-15\% terbaik yang dapat diterima di sekolah guru atau Kweekschool.

Ada beberapa alasan mengapa Kweekschool menjadi banyak peminat: pertama, pendidikan guru itu bebas dari pembayaran uang sekolah, bahkan setiap siswa menerima uang saku setiap bulan sehingga orang tua bebas dari pengeluaran lainya. Kedua, setiap lulusan sudah dapat dipastikan untuk mendapat pekerjaan di sekolah pemerintah dengan gaji yang baik, serta mendapatkan status yang terhormat di tengah masyarakat sebagai pemerintah/birokrat dan orang intelektual. Dalam jangka waktu yang lama, Kweekschool merupakan salah satu jalan yang langka bagi masyarakat golongan menengah dan rendah di kalangan orang Indonesia untuk menikmati pendidikan lanjutan. Tidak mengherankan jika tamatan sekolah guru, mereka lebih senang mengajar pada Sekolah Kelas Satu daripada di Sekolah Kelas Dua, karena pada umumnya mereka adalah berasal dari golongan menengah dan rendah. Mereka telah menerima dan hidup dalam norma-norma golongan menengah di Kweekschool maupun dalam profesinya sebagai guru.

Dengan demikian, pada akhir abad ke-19, ada tiga lapangan pekerjaan yang paling didambakan oleh masyarakat, tidak terkecuali oleh masyarakat Minangkabau ketika itu. Jenis pekerjaan tersebut adalah: menjadi Angku Guru, Angku Doto (Dokter), dan Angku Lareh (Laras) (Graves, 1981). Dengan naiknya status sosial guru dan dengan hasil atau gaji yang memadai, akhirnya menghasilkan guru-guru yang berkualitas pada akhir abad ke-19 sampai awal abad ke-20, khususnya menjelang kemerdekaan. Tidak mengherankan jika mereka adalah orang-orang yang nantinya menjadi kelompok kreatif minoritas (creative minority), pelopor kemerdekaan Republik ini.

Kebanyakan guru kemudian menjadi aktifis politik pergerakan dan menjadi pelopor perubahan di lingkungannya, akibat langsung dari hasil pendidikan kolonial yang diperolehnya (Zed, 1995). Penguasa kolonial merasa "kecolongan" ketika guru kemudian menjadi boomerang terhadap tuannya, tetapi merupakan rembesan "pencerahan" bagi kaum terpelajar bumi putra, setidaknya dalam dua hal: Pertama, sikap zakelik suatu istilah Belanda yang sulit 
diterjemahkan ke dalam bahasa Indonesia, namun cirinya dapat diterjemahkan dengan pengertian berdisiplin, dan perfeksionis. Kedua, guru-guru pada masa kolonial adalah panggilan profesi yang dipenuhi oleh segelintir kaum terpelajar yang berjiwa inovatif dalam "mengubah manusia" menjadi pribadi yang berharga. Dalam pengertian kontekstual, pekerjaan professional yang diembannya lahir dari semangat profesonalisme. Dengan demikian, guru zaman kolonial bukan hanya orang yang dianggap tahu dan berilmu pengetahuan di mata murid-muridnya, tetapi juga tempat bertanya dan minta nasehat bagi masyarakat.

Dalam posisinya yang mendapat tempat terhormat dalam masyarakat, para guru bukanlah penganut budaya diam (culture of Silience), (Shih, 2018; Veugelers, 2017)sebagaimana yang lazim dimilki oleh "elite tradisional" yang feodalistik, yang kemudian dipelihara oleh penguasa kolonial, atau kaum lemah yang miskin dan hidup dalam keadaan melarat. Guru adalah mandat masyarakat dan ketika politik pergerakan masuk ke sekolah-sekolah, guru-guru juga menjadi sarang kegiatan politik. Akibatnya salah satu alasan penting mengapa pemerintah kolonial akhirnya menerapkan Ordonansi Guru dan kemudian disusul dengan Ordonansi Sekolah Liar di awal tahun 1930-an adalah karena guru-guru dan sekolah-sekolah sudah dicelupi jiwa nasionalisme yang terang akan mengancam status quo (Zed, 1995).

\section{Guru setelah fase Kemerdekaan}

Fase kemerdekaan sampai menjelang fase reformasi sebetulnya adalah sebuah fase yang sangat panjang, jika berdiskusi sejarah guru di Indonesia. Namun fase ini, akan menjelaskan di mana dan kapan terjadi tanda-tanda penting dalam kehidupan dan peran guru di Indonesia dalam kaitannya dengan perubahan kualitas pendidikan. Awal-awal kemerdekaan, tepatnya sampai 1949, tidak terdapat sekolah guru dalam artian formal di Indonesia dan sekaligus tidak ada pengangkatan untuk guru-guru. Pada periode ini, karena masih dalam mengisi semangat nasionalisme, maka guru-guru keluaran zaman kolonial masih memainkan peranan pentingnya di dunia pendidikan. Mereka menjadi pendidik dan guru tampa meminta imbalan materi.

Terputusnya mata rantai dan kelangkaan guru yang luar biasa terjadi pada masa Orde Baru. Pertumbuhan penduduk yang meningkat, akhirnya membutuhkan tenaga guru yang tidak sedikit. Peristiwa ini disambut dengan sistem Negara Orde Baru yang hegemonik dan sentralistik. Sekitar tahun 1980-an, kita mengenal pengangkatan guru yang gila-gila dengan tanpa perencanaan yang matang. Di Sumatera Barat disebut dengan "Guru Galodo", karena 
Siti Fatimah, Firza

Guru dan Kualitas Pendidikan di Indonesia Masa Kolonial

dan Pasca Kemerdekaan

beriringan dengan terjadinya peristiwa Galodo di daerah ini. Sebagaimana halnya pernah terjadi di zaman kolonial, siapa yang bersedia dan berminat menjadi guru, meskipun bukan berlatar belakang pendidikan guru langsung akan diangkat menjadi guru (PNS), dengan persyaratan, bersedia ditempatkan sesuai dengan daerah yang membutuhkan. Pada umumnya mereka adalah berasal dari lulusan SMA (Sekolah Menengah Atas), sekolah kejuruan, seperti STM (Sekolah Teknik Menengah) dan SMEA (Sekolah Managemen Atas). Kemudian setelah ditempatkan pada sekolah yang dituju, mereka diberi penataran setaraf dengan D1 atau D2.

Peristiwa ini merupakan awal menurunya kualitas pendidikan di Indonesia yang disebabkan oleh kebijakan Negara terhadap pola rekruitmen guru. Di samping banyaknya persoalan lain yang membuat kualitas pendidikan Indonesia berada pada urutan paling rendah. Guru-guru ini pada umumnya sudah bertugas sekitar tiga puluh tahun sampai sekarang dan pada umumnya mereka belum pensiun. Pada saat ini, mereka dalam proses sertifikasi. Seiring dengan meningkatnya kebutuhan-kebutuhan guru pada periode-periode tertentu, menjamur pula berdirinya LPTK-LPTK swasta hampir di seluruh wilayah Indonesia.

\section{Guru di Era Reformasi}

Keluarnya Undang-Undang tentang sertifikasi guru dan dosen, mengingatkan kita kepada sistem kebijakan pemerintahan kolonial pada akhir abad ke-19. Artinya, ada beberapa keinginan pemerintah untuk memperbaiki mutu pendidikan melalui dimensi guru (Nasution, 2008; Raharjo, 2012). Pertama, meningkatkan kualitas guru melalui peningkatan kualifikasi atau jenjang pendidikan yang lebih tinggi, bahkan harus linear. Kedua, menaikkan gaji guru yang sudah lulus sertifikasi satu kali gaji pokok yang sudah ada. Untuk keperluan ini pemerintah sudah menempatkan anggaran tertinggi untuk pendidikan melalui APBN dan APBD dibanding sektor-sektor lainnya. Dampak yang dirasakan profesi guru mulai sebuah profesi yang diperhitungkan.

Dampak yang muncul hingga saat ini, belum terlihat akan hadirnya tanda-tanda perbaikan dalam kualitas pendidikan. Apalagi seperti yang diharapkan sesuai dengan keberadaan guru pada awal-awal kebangkitan nasional. Kondisi saat ini terlihat sangat banyak persoalan yang berhubungan dengan kualitas pendidikan di Indonesia. Sudah tidak menjadi rahasia lagi, bahkan sudah menjadi konsumsi publik bahwa di mana-mana terjadi kecurangan dalam ujian nasional, dan itu secara tidak langsung diketahui dan dibiarkan oleh para gurunya. Bahkan di beberapa sekolah justru guru yang 
bergerilya mencari informasi tentang kunci soal untuk diberikan kepada para siswanya (dihimpun dari data observasi lapangan selama tahun ajaran 20162018).

Alternatif lain yang sedang dirancang dalam rangka meningkatkan kualitas pendidikan adalah akan hadirnya program Pendidikan Profesi Guru (PPG). Program ini direncanakan sudah terrealisasi pada tahun 2011. Mahasiswa yang masuk program ini sudah dipastikan akan menjadi guru, dan jumlah mahasiswa yang diterima dalam program ini berdasarkan analisis kebutuhan guru di masing-masing daerah. Pemerintah juga menentukan kualifikasi LPTK yang berhak untuk membuka program ini. Namun lagi-lagi persoalan yang tampak adalah pemerintah belum sepenuhnya siap untuk menjalankan program ini. Hal ini dapat dilihat dari beberapa persyaratan dan kualifikasi yang diminta banyak yang diturunkan, misalnya untuk persyaratan dosen yang mengajar, seharusnya berkualifikasi latar pendidikan atau LPTK, adanya sekolah mitra, tersedianya labor micro teaching yang memadai. Hasilnya, keraguan yang muncul adalah program ini, tidak memiliki perbedaan yang substansi di banding dengan jalur S1 LPTK selama ini. Hal yang sama terjadi dalam program sertifikasi guru. Sebuah persoalan yang sangat dilematis dalam dunia pendidikan kita saat ini. Oleh karena itu, dengan program PPG ke depan yang akan diterima dalam program tersebut adalah sesuai dengan kebutuhan guru ke depan. Mudahmudahan dengan program ini akan dapat menjawab kualitas pendidikan ke depan ke arah yang lebih baik. Namun kebijakan ini sudah mulai dilakukan tetapi masih sangat terbatas.

\section{Simpulan}

Permasalahan pendidikan di Indonesia masih menjadi permasalahan yang harus menjadi perhatian bersama. Terlepas dari permasalahan tersebut profesi guru menjadi sangat diminati oleh masyarakat. Hal ini dapat dibuktikan dengan tingginya peminat untuk memasuki jurusan-jurusan yang ada di lembaga LPTK. Di samping itu, semakin menjamurnya lembaga LPTK swasta, hal ini tentu sejalan dengan apa yang telah terjadi pada masa kolonial, yaitu: semakin besarnya gaji guru berkaitan dengan status sosial guru yang mulai diperhitungkan, karena hampir semua guru saat ini kehidupan sudah sejahtera. Namun mencari sosok guru seperti yang dijelaskan pada bagian atas, mungkin sangat sulit pada saat ini. Oleh karena itu yang perlu difikirkan adalah alternatif 
Siti Fatimah, Firza

Guru dan Kualitas Pendidikan di Indonesia Masa Kolonial

dan Pasca Kemerdekaan

apa yang bisa dibuat dan dilakukan agar citra guru jujur, disiplin dan professional itu benar-benar bisa menjadi kenyataan.

\section{Daftar Rujukan}

Agung, I. A. A. G. (1993). Kenangan masa lampau: zaman kolonial Hindia Belanda dan zaman pendudukan Jepang di Bali. Yayasan Obor Indonesia.

Anwar, A. S. (2020). Pengembangan Sikap Profesionalisme Guru Melalui Kinerja Guru Pada Satuan Pendidikan MTS Negeri 1 Serang. Andragogi: Jurnal Pendidikan Islam Dan Manajemen Pendidikan Islam, 2(1), 147-173.

Anwar, M. (2018). Menjadi guru profesional. Prenada Media.

Arifin, S. (2019). Pengembangan Bahan Ajar Sejarah Organisasi Keagamaan Masa Pergerakan Kebangsaan Indonesia Kelas XI Madrasah Aliyah Negeri Demak. Universitas Negeri Semarang.

Bugge, H. (2020). Mission and Tamil Society: Social and Religious Change in South India (1840-1900). Routledge.

Chu, S. K. W., Reynolds, R. B., Tavares, N. J., Notari, M., \& Lee, C. W. Y. (2021). 21st century skills development through inquiry-based learning from theory to practice. Springer.

Counts, G. S. (1978). Dare the school build a new social order? (Vol. 143). SIU Press.

Dyokta, N. A. D. (2020). Profesi Guru Sejarah antara Tantangan dan Peluang Menjadi Guru Milenial di Era 4.0. Khazanah: Jurnal Edukasi, 2(2), 115-125.

Febriana, R. (2021). Kompetensi guru. Bumi Aksara.

Firdianti, A. (2018). Implementasi manajemen berbasis sekolah dalam meningkatkan prestasi belajar siswa. Gre Publishing.

Giroux, H. (2020). Critical pedagogy. Springer.

Graves, E. (1981). The Minangkabau Response to the Dutch Colonial Rule in Nineteeenth Century. Ithaca.

Grossman, P., \& McDonald, M. (2008). Back to the future: Directions for research in teaching and teacher education.

Hans, N. (2012). Comparative education: A study of educational factors and traditions. Routledge.

Heyman, J., \& Jacques, H. (1998). Structural analysis: a historical approach. Cambridge University Press.

Kurniawan, R. Y. (2016). Identifikasi permasalahan pendidikan di Indonesia untuk meningkatkan mutu dan profesionalisme guru. Konvensi Nasional Pendidikan Indonesia, 1415-1420.

Lak, A., Gheitasi, M., \& Timothy, D. J. (2020). Urban regeneration through heritage tourism: cultural policies and strategic management. Journal of Tourism and Cultural Change, 18(4), 386-403.

Mahoney, J., \& Rueschemeyer, D. (2003). Comparative historical analysis. Comparative Historical Analysis in the Social Sciences, 3.

Mirowsky, J., \& Ross, C. E. (2017). Education, social status, and health. Routledge. 
Munirom, A. (2021). MANAJEMEN PENINGKATAN MUTU PENDIDIKAN. Jurnal An-Nur: Kajian Ilmu-Ilmu Pendidikan Dan Keislaman, 7(1), 154-174.

Nasution. (2008). Sejarah Pendidikan di Indonesia.

Nur, A. (2011). Ulama dalam Dinamika Sosial dan Budaya Masyarakat Aceh di Awal Abad Kedua Puluh Satu. Jurnal Humaniora, 23(3), 315-325.

Phillips, D. (2006). Comparative education: method. Research in Comparative and International Education, 1(4), 304-319.

Priscilla, D. (2019). Permasalahan Pendidikan di Indonesia.

Purba, S., Subakti, H., Kato, I., Chamidah, D., Muntu, D. L., Cecep, H., Situmorang, K., \& Saputro, A. N. C. (2021). Teori Manajemen Pendidikan. Yayasan Kita Menulis.

Raharjo, S. B. (2012). Evaluasi trend kualitas pendidikan di indonesia. Jurnal Penelitian Dan Evaluasi Pendidikan, 16(2), 511-532.

Risdiany, H. (2021). Pengembangan Profesionalisme Guru Dalam Mewujudkan Kualitas Pendidikan Di Indonesia. AL-HIKMAH (Jurnal Pendidikan Dan Pendidikan Agama Islam), 3(2), 194-202.

Shehabat, I. M., \& Berrish, M. (2021). Integration between knowledge management and total quality management in Jordanian Universities: Empirical study. In Research Anthology on Preparing School Administrators to Lead Quality Education Programs (pp. 1405-1436). IGI Global.

Shih, Y. H. (2018). Some Critical Thinking on Paulo Freire's Critical Pedagogy and Its Educational Implications. International Education Studies, 11(9), 64-70.

Siregar, N. H. (2020). Pengembangan Kualitas Pendidikan Di Indonesia Dilakukan Melalui Peningkatan Profesionalitas Guru. Jurnal Penelitian, Pendidikan Dan Pengajaran: JPPP, 1(1).

Smith, S. J. (2019). Inviting a Change to the Status Quo in Education: Using Keating's Pedagogies of Invitation. Philosophical Studies in Education, 50, 150159.

Sormin, D. (2021). Manajemen Mutu Guru. umsu press.

Tilaar, H. A. R. (2003). Kekuasaan dan pendidikan: Suatu tinjauan dari perspektif studi kultural. IndonesiaTera.

Ukpokodu, O. (2009). The practice of transformative pedagogy. Journal on Excellence in College Teaching, 20(2), 43-67.

Veugelers, W. (2017). The moral in Paulo Freire's educational work: What moral education can learn from Paulo Freire. Journal of Moral Education, 46(4), 412421.

Wardani, K. (2010). Peran guru dalam pendidikan karakter menurut konsep pendidikan Ki Hadjar Dewantara. Proceeding of The 4th International Conference on Teacher Education; Join Conference UPI EUPSI, 8-10.

Wasino, W., \& Hartatik, E. S. (2019). Rice Policy in Java from Traditional Kingdoms to Dutch Colonial Time. KnE Social Sciences, 730-735.

Wijaya, C., Nasution, T., Al Qadri, M., Fuadi, A., \& Anwar, K. (2021). Persepsi Guru RA Ali Mahfudz tentang Kebijakan Sertifikasi Guru dalam Peningkatan Mutu Pendidikan. Jurnal Obsesi: Jurnal Pendidikan Anak Usia Dini, 6(2), 738-751. 
Siti Fatimah, Firza

Guru dan Kualitas Pendidikan di Indonesia Masa Kolonial

dan Pasca Kemerdekaan

Wijaya, I. (2018). Professional Teacher: Menjadi Guru Profesional. CV Jejak (Jejak Publisher).

Zed, M. (1995). Pendidikan Keguruan dan Krisis Ilmu Pengatahuan Dewasa ini. 